\title{
Faktor - faktor Praktek Sumber Daya manusia yang Mempengaruhi Kinerja karyawan Perusahaan Garmen di Batam
}

\author{
Yuswardi \\ Universitas Internasional Batam \\ yuswardi003@gmail.com
}

\begin{abstract}
Abstrak
Penelitian ini dilakukan dengan tujuan untuk mengetahui pengaruh dari variabel rekrutmen dan seleksi, pelatihan kerja, kompensasi, dan penilaian kinerja terhadap kinerja karyawan pada karyawan perusahaan yang bergerak di bidang garmen atau garmen di Batam.

Peneliti menyebarkan kuesioner pada 360 responden untuk mendapatkan data yang akan diolah dalam penelitian ini. Metode survei digunakan agar lebih mudah dalam mengukur variabel yang diuji. Karyawan dari perusahaan garmen yang berada di Batam dijadikan responden dalam penelitian ini. Setelah kuesioner disebarkan berhasil dikumpulkan 355 kuesioner untuk uji data dengan program SPSS.

Hasil penelitian ini menunjukkan adanya pengaruh signifikan dari variabel independen terhadap dependen. Penulis menyimpulkan bahwa variabel rekrutmen dan seleksi berpengaruh signifikan terhadap kinerja karyawan sehingga proses yang sesuai prosedur dan seleksi yang ketat akan menghasilkan karyawan yang tepat untuk posisi yag dibutuhkan oleh perusahaan. Demikian pula untuk variabel lain yang diteliti, semua mempunyai pengaruh yang signifikan terhadap variabel dependen sehingga perusahaan garmen di Batam harus bisa menerapkan variabel tersebut dengan baik di lapangan.
\end{abstract}

Kata Kunci perusahaan garmen, rekrutmen dan seleksi, pelatihan, kompensasi, penilaian kinerja, kinerja karyawan

\section{PENDAHULUAN}

Kota Batam merupakan kota yang berkembang dalam berbagai sektor industri yang terus berkembang dan memiliki potensi ekonomi yang baik dan memiliki sumber daya manusia yang terlatih menjadikan kota Batam sebuah daerah yang memiliki tingkat pertumbuhan ekonomi dan penduduknya yang tinggi. Dengan adanya hal tersebut menjadikan kota Batam menjadi daya tarik tersendiri untuk para investor untuk membuka bisnis di sektor manufacturing di kota Batam karena letak geografis Batam yang mendukung, berlokasi dekat dengan negara Singapura yang merupakan sebuah hub dalam perdangan internasional. Dengan berbagai keuntungan dan nilai tambah tersebut menarik sejumlah investor untuk membuka perusahaan garmen di kota Batam antara lain PT. Ghim Li, PT. Bintan Bersatu Apparel dan PT. Shallwin Enterprise dan beberapa perusahaan lainnya.

Dalam menjalankan perusahaan, dibutuhkan tenaga kerja atau sumber daya manusia yang terlatih dan memiliki dedikasi yang tinggi dalam melakukan pekerjaannya. 
Sumber daya manusia yang terlatih dianggap sebagai faktor pendorong utama dalam menentukan kesuksesan sebuah perusahaan tersebut. Sumber daya lainnya yang di miliki perusahaan tersebut seperti mesin, keuangan dan metode tidak dapat memberikan hasil yang terbaik apabila tidak di dukung oleh sumber daya manusia yang memiliki keterampilan yang tinggi. Karena dengan tersedianya tenaga kerja yang terampil dalam melaksanakan pekerjaannya maka tujuan dan sasaran perusahaan akan lebih mudah tercapai.

Perusahaan selalu ingin agar karyawannya dapat bekerja dengan maksimal, dengan demikian untuk mengikatkan kinerja para karyawan kepada perusahaan, maka perusahaan tersebut harus mampu menigkatkan dan megembangkan kreativitas dari para karyawan. Oleh karena itu perusahaan harus melakukan perberdayaan terhadapat karyawannya karena itu merupakan bagian yang penting dalam rangka menjamin agar para karyawan memiliki sifat yang kompetitif dalam melaksanakan kerjanya. Adanya kepuasan kerja karyawan tidak dapat terlepas dari adanya beberapa faktor-faktor yang mempergaruhi karyawan tersebut. Untuk dapat membuat seorang karyawan merasakan kepuasan kerja, karyawan tersebut harus memiliki lingkungan kerja yang baik dan rekan kerja yang membantu dalam menjalakan tugasnya. Permasalahan budaya perusahaan merupakan hal yang penting karena akan selalu berhubungan dengan kehidupan di dalam perusahaan. Budaya perusahaan merupakan sebuah ideologi, nilai-nilai dan norma-norma yang dimiliki secara bersama serta mengikat dalam suatu komunitas perusahaan.

Rekrutmen dan seleksi merupakan sebuah proses untuk menghasilkan sekumpulan pelamar yang potensial untuk melamar pada sebuah posisi pekerjaan dalam sebuah organisasi. Seleksi merupakan sebuah proses dimana penggunaan instrumen tertentu dalam memilih dan menentukan dari sekelompok pelamar yang paling sesuai untuk pekerjaan tersebut dengan mempertimbangkan tujuan manajemen dan persyaratan yang ditentukan (Tanveer et al., 2011). Pelatihan kerja merupakan sebuah proses yang mengajarkan pengetahuan dan keahlian serta sikap dalam meningkatkan keterampilan dan kemampuan karyawan dalam melaksanakan tugas dan tanggung jawabnya dengan baik dan sesuai standar perusahaan. Pelatihan merupakan salah satu usaha dan upaya dalam meningkatkan mutu sumber daya manusia dalam sebuah perusahaan. (Tanveer et al. 2011).

\section{LANDASAN TEORI}

Jouda et al., (2016) meneliti hubungan dan pengaruh dari variabel independen yaitu seleksi dan rekrutmen, pelatihan dan pengembangan, kompensasi dan penilaian kinerja terhadap kinerja karyawan sebagai variabel dependen. Penelitian ini dilakukan oleh Jouda et al., (2016) dengan menyebarkan kuesioner pada karyawan dan dosen di Universitas Islam Gaza, Palestina. Penelitian ini dilakukan untuk mengetahui seberapa besar pengaruh dari semua variabel independen yang diteliti diatas pada kinerja karyawan di universitas yang berada di wilayah konflik di Palestina. Hasil penelitian menunjukkan bahwa semua variabel yang diuji menunjukkan adanya hubungan yang signifikan psitif terhadap variabel dependen.

Dalam penelitian ini, Kaveri \& Prabakaran (2013) meneliti pengaruh dari variabel pelatihan kerja, motivasi, lingkungan kerja dan kompensasi sebagai variabel independen terhadap kinerja karyawan sebagai variabel dependen. Penelitian ini dilakukan pada karyawan dari sebuah perusahaan pengolahan kulit di India dan hasil penelitian 
menunjukkan bahwa terdapat hubungan yang signifikan antara semua variabel independen yang diuji terhadap kinerja karyawan. Industry pengolahan merupakan salah satu industry yang berkembang dengan pesat di India, sehingga dengan adanya penelitian ini diharapkan sektor industri semakin berkembang lagi karena kinerja karyawan yang meningkat.

Penelitian Tanveer et al., (2011) ini meneliti hubungan antara praktek sumber daya manusia dan dan pengaruhnya pada kinerja karyawan pada perusahaan tekstil di Pakistan. Variabel independen yang diteliti dalam penelitian ini adalah rekrutmen dan seleksi, pelatihan kerja dan penilaian kinerja dan kinerja karyawan sebagai variabel dependennya. Hasil penelitian menunjukkan adanya hubungan antara semua variabel independen terhadap kinerja karyawan. Industri tekstil di Pakistan cukup berkembang dengan baik karena mutu produk tekstil Pakistan sudah dikenal dengan industri ini dan untuk mempertahankan kualitas produk maka kinerja karyawan juga harus ditingkatkan.

Penelitian oleh Bowra et al., (2011) ini untuk menguji hubungan dan pengaruh dari elemen praktek sumber daya manusia yaitu kompensasi, evaluasi kinerja, dan promosi karyawan terhadap kinerja karyawan. Penelitian dilakukan dengan menyebarkan kuesioner pada karyawan di sektor industri perbankan di Pakistan. Hasil penelitian ini menunjukkan terdapat hubungan antara praktek sumber daya manusia terhadap kinerja karyawan sebagai variabel dependen.

Penelitian Shabbir (2014) yang meneliti mengenai hubungan dan pengaruh dari variabel independen yaitu praktek pengupahan, evaluasi kinerja dan kebijakan promosi karyawan terhadap kinerja karyawan pada karyawan perusahaan sektor industri farmasi di Pakistan. Hasil penelitian Shabbir (2014) ini menunjukkan adanya pengaruh antara variabel kompensasi, evaluasi kinerja dan promosi karyawan terhadap peningkatan kinerja karyawan perusahaan farmasi..

\section{Definisi Variabel Dependen}

\section{Kinerja Karyawan}

Menurut Tabiu \& Nura (2013), kinerja karyawan adalah hasil kerja karyawan yang diberikan pada perusahaan atau perusahaan yang dapat diukur dengan standar kerja yang ditetapkan bersama. Tercapainya tujuan sebuah perusahaan tidak terlepas dari kemampuan atau kompetensi sumber daya manusia yang berkualitas dan berkomitmen dalam upaya mencapai tujuan sebuah organisasi.

Menurut Bida et al., (2017) kinerja karyawan merupakan hasil usaha dan kerja secara kualitas dan kuantitas yang dilakukan karyawan dalam melaksanakan tugasnya sesuai dengan tanggung jawab yang diberikan kepadanya dibandingkan dengan prestasi yang diharapkan dari karyawan. Kinerja merupakan implementasi kerja dalam menjalankan aktivitas yang sesuai strategi dalam berbagai aktivitas teknis, taktik dan praktis sesuai dengan tujuan yang ingin dicapai bersama.

\section{Hubungan Antar Variabel}

\section{Pengaruh Rekrutmen dan Seleksi terhadap Kinerja Karyawan}

Menurut Tabiu \& Nura (2013), rekrutmen merupakan sebuah proses dalam menghasilkan sekelompok pelamar yang potensial untuk menempati sebuah posisi pekerjaan yang dibutuhkan dalam sebuah perusahaan sedangkan seleksi adalah proses dimana penggunaan instrumen tertentu yang sesuai untuk memilih kandidat yang paling 
sesuai untuk pekerjaan tersebut dari sekelompok pelamar dengan mempertimbangkan tujuan perusahaan dan persyaratan yang sudah ditentukan.

Proses rekrutmen dan seleksi adalah salah satu fungsi sumber daya manusia yang paling penting karena merupakan titik masuk kandidat karyawan ke dalam sebuah organisasi. Kemajuan sebuah perusahaan dapat ditentukan ketika perusahaan mampu merekrut calon karyawan yang sesuai dan mempunyai kemampuan dan komitmen kerja yang baik bagi kemajuan sebuah organisasi. Penelitian sebelumnya dari Jouda et al., (2016), Tanveer et al., (2011), Bida et al., (2017) dan Al Qudah et al. (2014) menunjukkan adanya hubungan antara rekrutmen dan seleksi dengan kinerja karyawan.

\section{Pengaruh Kompensasi terhadap Kinerja Karyawan}

Menurut Hussain dan Rehman (2013), kompensasi merupakan pemberian atau sesuatu yang diterima karyawan sebagai balas jasa atas kinerja dan usahanya kepada perusahaan dalam hal pekerjaan. Kompensasi bisa diberikan dalam bentuk finansial yang bersifat tunai seperti gaji, upah, tunjangan, bonus, insentif dan lain-lain. Imbalan yang bersumber dari luar diri karyawan yang biasanya diberikan oleh perushaan disebut imbalan ekstrinsik. Menurut Shabbir (2014), setiap perusahaan dalam operasionalnya selalu berkaitan dengan kompensasi yang merupakan salah satu hal penting dalam meningkatkan kinerja karyawan. Oleh sebab itu dalam meningkatkan kinerja karyawan dibutuhkan pemenuhan kompensasi untuk mendukung motivasi kerja karyawan. Sangat penting untuk menciptakan suatu hubungan kerjasama yang baik antara karyawan dengan perushaan sebagai pemberi kerja. Bila hubungan ini terjalin dengan baik maka akan mudah mencapai tujuan suatu perusahaan. Kedua pihak harus saling mengerti tentang kepentingan dan kebutuhan masing-masing dalam suatu perusahaan. Kebutuhan perusahaan akan terpenuhi melalui pekerjaan yang dilakukan oleh karyawan, dan melalui pekerjaan tersebut karyawan berharap mendapatkan kompensasi yang sesuai dengan kontribusinya bagi perusahaan. Kompensasi non finansial berupa pemberian lingkungan kerja yang aman, nyaman dan kondusif. Sedangkan kompensasi dalam bentuk finansial berupa pemberian gaji atau upah, insentif, tunjangan, bonus. Penelitian sebelumnya dari Kaveri \& Prabakaran (2013), Shabbir (2014) dan Jouda et al., (2016) menunjukkan adanya hubungan yang signifikan antara kompenssi dan kinerja karyawan.

\section{Pengaruh Pelatihan Kerja terhadap Kinerja Karyawan}

Pelatihan kerja merupakan modifikasi perilaku yang formal dan sistematis melalui pembelajaran melalui pendidikan, pengajaran, pengembangan dan pengalaman yang diberikan secara sistematis dan terukur (Tanveer et al., 2011). Pelatihan dapat dilakukan pada lokasi di lingkungan maupun diluar lingkungan pekerjaan tergantung pada kebutuhan dan rencana perusahaan. Pelatihan karyawan yang tepat diperlukan untuk meningkatkan kinerja, kompetensi, kemampuan kerja dan untuk pembangunan yang berkelanjutan dari sumber daya manusia yang dimiliki perusahaan. Penelitian sebelumnya dari Tanveer et al., (2011), Hussain dan Rehman (2013), Bida et al., (2017) dan Bercu (2017) menunjukkan adanya hubungan yang signifikan antara pelatihan dan kinerja karyawan. 


\section{Pengaruh Penilaian Kinerja terhadap Kinerja Karyawan}

Menurut Jouda et al., (2016), penilaian kinerja adalah sebuah proses untuk mengevaluasi kinerja karyawan dibandingkan dengan standar kerja yang ditetapkan oleh perusahaan dan kemudian mengkomunikasikan informasi tersebut pada karyawan untuk tujuan perbaikan dan peningkatan prestasi kerja. Penilaian kerja juga dibutuhkan karyawan dalam proses intropeksi keemampuan diri terhadap sebuah jabatan dalam pekerjaan.

Menurut Shabbir (2014), penilaian atau evaluasi kinerja adalah proses wajib yang dilakukan perusahaan, di mana perusahaan mengevaluasi sikap dan atau kualitas pekerjaan dari karyawan di sebuah perusahaan dalam satu jangka waktu tertentu. Penilaian kinerja ini menjadi masukan tentang kekuatan dan kelemahan seorang karyawan. Penilaian kinerja berperan penting dalam mengembangkan perusahaan melalui proses peningkatan efisiensi kerja karyawan (Shabbir, 2014).

\section{Perumusan Hipotesis}

Hipotesis untuk penelitian ini dirumuskan sebagai berikut:

H1: Terdapat pengaruh antara rekrutmen dan seleksi terhadap kinerja karyawan

H2: Terdapat pengaruh antara kompensasi terhadap kinerja karyawan

H3: Terdapat pengaruh antara pelatihan kerja terhadap kinerja karyawan

H4: Terdapat pengaruh antara penilaian kinerja terhadap kinerja karyawan

\section{METODE PENELITIAN}

\section{Objek Penelitian}

Populasi dalam penelitian ini adalah karyawan dari perusahaan yang bergerak dalam industri garmen di kawasan Batam Centre yaitu lain PT. Ghim Li PT. Bintan Bersatu Apparel dan PT. Shallwin Enterprise. Karyawan perusahaan garmen dipilih sebagai objek penelitian karena sektor industri garmen terutama untuk pasaran ekspor cukup berkembang dan menjanjikan di Batam. Jumlah sampel penelitian ditentukan dengan menggunakan Tabel Krejcie Morgan, dengan jumlah populasi 1,015 maka sampel penelitian minimum yang diperlukan berjumlah 278 responden. Tetapi untuk mengantisipasi adanya kuesioner yang tidak kembali atau tidak diisi dengan lengkap, maka jumlah kuesioner yang disebarkan adalah sebanyak 360 responden. Dari masing masing perusahaan diambil 120 sampel penelitian sehingga total berjumlah 360 responden.

\section{Teknik Pengumpulan Data}

Dalam melaksanakan penelitian ini, penulis menggunakan data primer yang dikumpulkan dengan cara penyebaran kuesioner kepada sekelompok responden yang menjadi objek penelitian. Kuesioner berisi pertanyaan umum untuk mengetahui demografi responden serta pertanyaan yang berasal dari masing masing variabel yang di uji sedangkan data sekunder didapatkan dari hasil penelitian terdahulu, jurnal penelitian, buku yang berkaitan dengan penelitian dan juga artikel atau data yang didapatkan dari sumber situs internet.

Penulis menyebarkan kuesioner pada responden secara langsung agar penulis bisa menjelaskan mengenai tujuan dan manfaat penelitian pada calon responden, serta dapat 
meyakinkan meeka bahwa informasi dalam kuesioner dijamin kerahasiaannya. Penyebaran sebagian kuesioner lainnya di lakukan dengan bantuan karyawan perusahaan dan disebarkan pada rekan kerja yang lainnya kemudian dikumpulkan kembali oleh penulis. Data yang diperlukan dalam penelitian ini adalah mengenai hubungan dan pengaruh rekrutmen dan seleksi, pelatihan kerja, kompensasi dan penilaian kerja sebagai variabel independen terhadap kinerja karyawan sebagai variabel dependen pada karyawan perusahaan garmen di Batam.

\section{HASIL PENELITIAN}

\section{Statistik Deskriptif}

Kuesioner yang disebarkan sebanyak 360 lembar pada karyawan dari tiga perusahaan di bidang garmen di kota Batam. Ada 5 kuesioner yang tidak kembali, sehingga jumlah kuesioner yang bisa digunakan dalam pengolahan SPSS adalah 355 kuesioner saja. Responden terdiri dari responden laki-laki sebanyak 119 orang dan responden perempuan sebanyak 236 responden. Hasil uji demografi responden berdasarkan usia. Terdapat 118 responden yang berusia 18 - 25 tahun, sebanyak 132 responden berusia antara 26 - 35 tahun, 79 responden penelitian berusia 36 - 40 tahun dan 26 responden yang berusia diatas 40 tahun. Hasil uji demografi responden berdasarkan tingkat pendidikan. Ada 226 orang responden yang berpendidikan terakhir SMA atau SMK, sebanyak 75 responden mempunyai ijazah tingkat Diploma dan sebanyak 54 responden yang bergelar Sarjana. Berdasarkan lama kerja terdapat 135 orang responden dengan masa kerja 1-3 tahun, 143 responden dengan lama kerja 4-6 tahun, dan sebanyak 77 responden dengan lama kerja > 6 tahun. Kemudian berdasarkan jumlah penghasilan responden perbulan. Dari data hasil uji demografi responden ini diketahui bahwa sebanyak 97 responden mempunyai penghasilan Rp 3-4 juta perbulan, 164 responden penelitian memiliki penghasilam berkisar dari Rp 5-6 juta dan 64 responden memiliki penghasilan lebih besar dari Rp 6 juta perbulan.

\section{Hasil Uji t}

Hasil uji H1 menunjukkan bahwa proses rekrutmen dan seleksi yang dilakukan oleh perusahaan sesuai dengan prosedur berhubungan signifikan positif terhadap kinerja karyawan perusahaan garmen di Batam. Dengan demikian bisa disimpulkan bahwa proses rekrutmen dan seleksi yang baik dalam penerimaan karyawan akan menentukan kinerja karyawan yang bagus. Hasil uji $\mathrm{H} 2$ menunjukkan bahwa variabel kompensasi berhubungan signifikan terhadap kinerja karyawan di Batam. Sistem kompensasi yang diterapkan pada karyawan di Batam bukan merupakan faktor utama dalam peningkatan kinerja karyawan. Hasil penelitian ini tidak konsisten dengan penelitian dari Hussain \& Rehman (2013), Asim (2013).

Hasil uji H3 menunjukkan bahwa program pelatihan yang dilakukan oleh perusahaan berhubungan signifikan positif terhadap kinerja karyawan perusahaan garmen di Batam. Dengan demikian bisa disimpulkan bahwa program pelatihan yang terencana dengan baik akan mempengaruhi kinerja karyawan perusahaan garmen di Batam. Hasil temuan ini konsisten dengan temuan dari penelitian dari Farooq dan Khan (2011), Hussain dan Rehman (2013) dan Amin et al., (2012). Hasil uji H4 menunjukkan bahwa penilaian kinerja karyawan berhubungan signifikan positif terhadap kinerja karyawan. 
Dengan demikian bisa disimpulkan bahwa penerapan program penilaian kinerja yang baik dan terencana akan mampu meningkatkan kinerja karyawan perusahaan garmen di Batam. Hasil ini konsisten dengan penelitian dari Tanveer et al., (2011) dan Iqbal et al., (2013).

\section{Hasil Uji Koefisien Determinasi $\left(\mathbf{R}^{2}\right)$}

Uji koefisien determinasi $\left(\mathrm{R}^{2}\right)$ dipergunakan untuk mengetahui besaran pengaruh antara variabel dependen dengan variabel independen. Dalam penelitian ini diketahui bahwa angka adjusted $\mathrm{R}^{2}$ sebesar 0,655 yang artinya bahwa kemampuan dari variabel independen dalam menjelaskan variabel kinerja karyawan adalah sebesar 65,5\% sedangkan sisanya yaitu $34,5 \%$ dijelaskan oleh variabel lain yang tidak diteliti dalam penelitian ini, seperti keterlibatan karyawan (Tabiu \& Nura, 2013).

\section{KESIMPULAN}

\section{Kesimpulan}

Hasil penelitian ini menyimpulkan bahwa terdapat pengaruh dan hubungan antara variabel rekrutmen dan seleksi karyawan terhadap kinerja karyawan pada perusahaan garmen di Batam. Hasil penelitian ini menunjukkan bahwa proses rekrutmen dan seleksi yang baik dan sesuai dengan prosedur dan praktek MSDM yang ditetapkan perusahaan untuk mendapatkan kandidat yang tepat bagi sebuah posisi sangatlah penting dan akan meningkatkan kinerja karyawan perusahaan garmen di Batam. Hasil temuan ini konsisten dengan penelitian dari Tanveer et al., (2011). Hasil pengujian ini juga menunjukkan bahwa variabel kompensasi berpengaruh signifikan terhadap pada tingkat kinerja pada karyawan perusahaan garmen di Batam. Temuan ini menunjukkan bahwa kompensasi merupakan faktor penting yang mempengaruhi kinerja karyawan perusahaan garmen di Batam. Hasil penelitian ini tidak konsisten dengan penelitian dari Hussain \& Rehman (2013), Asim (2013).

Hasil pengujian ini juga menyimpulkan bahwa terdapat pengaruh yang signifikan antara variabel pelatihan kerja terhadap kinerja karyawan. Hal ini menunjukkan bahwa program pelatihan yang diberikan oleh perusahaan akan meningkatkan kinerja dari karyawan perusahaan garmen di Batam. Hasil temuan ini konsisten dengan temuan dari penelitian dari Farooq dan Khan (2011), Hussain dan Rehman (2013) dan Amin et al., (2012). Hasil pengujian ini juga menyimpulkan bahwa variabel penilaian kinerja berpengaruh signifikan terhadap kinerja karyawan pada perusahaan garmen di Batam. Temuan ini menunjukkan bahwa sistem penilaian kerja karyawan yang berguna dalam mengevaluasi kinerja masing masing individu dalam perusahaan akan meningkatkan kinerja karyawan perusahaan garmen di Batam. Hasil ini konsisten dengan penelitian dari Tanveer et al., (2011) dan Iqbal et al., (2013).

\section{UCAPAN TERIMA KASIH}

Penulis mengucapkan terimakasih kepada Kepala Program Sarjana Manajemen Fakultas Ekonomi Universitas Internasional Batam, Dekan Fakultas Ekonomi Universitas Internasional Batam dan juga Rektorat Universitas Internasional Batam dan teman teman peneliti yang telah mendukung dan memberikan semangat pada peneliti untuk melakukan penelitian ini. 


\section{DAFTAR PUSTAKA}

Al-Qudah, M. K., Osman, A., Halim, M. S., dan Shatanawi, H. A., (2014). The Effect Of Human Resources Management Practices On Employee Performance. International Journal of Academic Research in Business and Social Sciences, Vol. 4 , No. 4.

Asim, M (2013). Impact of Motivation on Employee Performance with Effect of Training: Specific to Education Sector of Pakistan. International Journal of Scientific and Research Publications, Volume 3, Issue 9, September 20131 ISSN 2250-3153

Bercu, A.M (2017) Impact of Employees' Training Programmes on Job Performance. Current Science, Vol. 112, No. 1340 7, 10 April 2017

Bowra, Z., Sharif B., Saeed A., dan Niazi, M. (2011). Impact of Human Resource Practices on Employee Perceived Performance in Banking Sector of Pakistan. African Journal of Business Management, 6(1), 323-332.

Bida, M.J., Majid, A.H dan Ismail, A.I (2017) Establishing HR Practices-Employee Performance Relationship through Literature Survey. Journal of Advanced Research in Business and Management Studies 6, Issue 1 (2017) 39-49

Ghozali, I (2011). Aplikasi Analisis Multivariate dengan Program SPSS, Badan Penerbit Universitas Diponegoro, Semarang

Hair, J.F., Black, W.C., Babin, B.J., dan Anderson, R.E. (2010). Multivariate Data Analysis. Seventh Edition. Prentice Hall, Upper Saddle River, New Jersey.

Hussain, T. dan Rehman, S.S. (2013) Do Human Resource Management Practices Inspire Employees' Retention? Research Journal of Applied Sciences, Engineering and Technology 6(19): 3625-3633, 2013

Indriantoro, N dan Supomo, B (2012). Metedologi Penelitian Bisnis. Yogyakarta: Edisi Pertama, Penerbit BPFE.

Ibrar, M dan Khan, O. (2015) The Impact of Reward on Employee Performance. International Letters of Social and Humanistic Sciences Vol. 52 (2015) pp 95-103

Jagero, N. Komba, H.V dan Mlingi, M.D (2012) Relationship between on the Job Training and Employee's Performance in Courier. Companies in Dar es Salaam, Tanzania. International Journal of Humanities and Social Science Vol. 2 No. 22

Jouda, A.A., Ahmad, U.N., dan Dahleez, K.A. (2016) The Impact of Human Resource Management Practices on Employees Performance: The Case of Islamic University of Gaza in Palestine. International Review of Management and Marketing, 2016, 6(4), 1080-1088

Kaveri, M dan Prabakaran, G. (2013). Impact of High Performance Human Resource Practices on Employees' Job Performance in Leather Goods Manufacturing Companies at Vellore District. Bonfring International Journal of Industrial Engineering and Management Science, Vol. 3, No. 1, March 2013

Njanja, W.L., Maina, R.N, Kibet, L.K., dan Njagi, K (2013) Effect of Reward on Employee Performance: A Case of Kenya Power and Lighting Company Ltd., Nakuru, Kenya. International Journal of Business and Management; Vol. 8, No. $21 ; 2013$ 
Shabbir, M.S (2014). The Impact of Human Resource Practice on Employee Perceived Performance in Pharmaceutical Sector of Pakistan. African Journal of Business Management, Vol. 8 (15) pp 626-632

Tabiu, A dan Nura, A. A (2013). Assessing the Effects of Human Resources Management (HRM) Practices on Employee Job Performance. Journal of Business Studies Quarterly 2013, Volume 5, Number 2

Tanveer, Y, Shaukat, M. Z, Alvi, S.A dan Munir, A (2011) The Way Human Resource Management Practice Effect Employee Performance: A Case of Textile Sector. International Journal of Economics and Management Sciences Vol. 1, No. 4, 2011, pp. 112-117 